\title{
Práticas Educativas da Atenção Primária com Grupo de Gestantes Sobre a Humanização do Parto
}

\author{
Almeida, Janie Maria de; Campos, Sthéfani Parra A. de \\ Pontificia Universidade Católica de São Paulo — janie@pucsp.br
}

\begin{abstract}
Introdução: Durante o pré-natal, encontra-se uma oportunidade propicia para efetivar o preparo da mulher para viver a gestação e o parto de forma enriquecedora. o acompanhamento clínico com a prevenção de intercorrências e agravos na evolução da gestação, bem como o processo educativo são importantes para estimular a formação de vínculo da gestante com o serviço. Este cuidado possibilita uma participação ativa das mulheres no momento do pré-natal, parto e puerpério, pilar da humanização do parto. Os profissionais de saúde assumem uma posição de apoiadores e participantes desse processo, pois têm a oportunidade de colocar o conhecimento a serviço do bemestar da mulher, por meio de ações educativas em grupo, disseminando informações confiáveis, para minimizar o medo e ansiedade, normais neste período. Objetivos: Desenvolver ações educativas na atenção primária direcionadas a assistência pré-natal; instituir um espaço de discussão para gestantes em unidade básica de saúde e fornecer informações seguras sobre o processo de gestar e parir. Métodos: Trata-se de relato de uma atividade de extensão, desenvolvida no ano de 2013. Durante a consulta do pré-natal realizada por enfermeiras do programa do prénatal do município de Sorocaba, as gestantes foram convidadas a participar de encontros quinzenais, com foco na discussão de temas relacionados à gravidez e amamentação, a preparação física e emocional da gestante para o parto, além de abordar técnicas de respiração e relaxamento, métodos de alívio da dor do parto ancorados no referencial de humanização da assistência ao parto, do Ministério da Saúde. Esses encontros foram desenvolvidos por aluna e docente do curso de enfermagem. Resultados: Foram realizados 13 encontros do grupo de gestantes, o número de participantes variou entre uma até 15 mulheres, com a média de 5 gestantes por grupo. Além das gestantes, participaram também puérperas e acompanhantes, como: parceiros, mães, sogras e filhos, que permitiu uma troca de experiências significativas mediante depoimentos sobre o parto. a faixa etária das gestantes variou de 14 a 38 anos, a maioria delas eram primíparas. a dinâmica do grupo era flexível, baseadas nas questões que emergiram, o questionamento mais freqüente foi com relação à dor do parto e quanto ao atendimento na maternidade, sendo o ponto principal a presença de acompanhante. a abordagem desses temas envolveu o incentivo de práticas de conforto como banhos de chuveiro, massagens, relaxamento, respiração e técnicas para alívio da dor. Conclusões: Foi possível constatar um interesse crescente das gestantes e a interação descontraída durante o desenrolar das atividades. Ficou patente a falta de informações que cercam o período da gestação. Praticar a escuta e valorizar ações educativas durante o pré-natal estimulam a transformação de conceitos em relação ao parto e reforçam a adoção de condutas de humanização na assistência ao parto.
\end{abstract}

Almeida, Janie Maria de; Campos, Sthéfani Parra A. de. Práticas Educativas da Atenção Primária com Grupo de Gestantes Sobre a Humanização do Parto. In: Anais do Congresso Internacional de Humanidades \& Humanização em Saúde [= Blucher Medical Proceedings, num.2, vol.1]. São Paulo: Editora Blucher, 2014. ISSN 2357-7282 DOI 10.5151/medpro-cihhs-10512 